Steffen Tangen

Høgskolen i Østfold

Birgitte Nordahl Husebye

Høgskolen i Østfold

DOI: http://dx.doi.org/10.5617/adno.4812

\title{
Interessebasert kroppsøving
}

\section{Sammendrag}

Forskning indikerer at kroppsøvingsfaget slik det presenteres i dag, ikke oppleves meningsfullt for alle elever, og med den rådende sportsdiskurs kan faget for noen virke mot sin hensikt (Säfvenbom, Haugen \& Bulie, 2015). Vi vet lite om hvordan ulike organiseringsformer av kroppsøvingsfaget kan gjøre faget mer meningsfullt for flere elever. I denne studien undersøker vi gjennom kvalitative forskningsintervjuer med fem elever og et fokusgruppeintervju med fire larere hvordan elever uttrykker seg om kroppsøving og egen motivasjon når de får mulighet til å gjennomføre en ny organiseringsform for kroppsøvingsfaget, «interessebasert kroppsøving» (IBKRØV). Organiseringsformen lar elevene få velge mellom to varianter av kroppsøving: «idrettsglede» og «bevegelsesglede». Begge variantene arbeider mot de samme kompetansemålene, men tilnæermingsmåten er ulik. Bevegelsesglede har en lekende tilncerming til aktivitet, mens idrettsglede fokuserer mer på idrettslig utvikling. Hovedideen med IBKRØV er at elevene skal få velge et kroppsøvingsfag med utgangspunkt i egne bevegelseserfaringer, verdier og interesser. Det ser ut som om IBKRØV klarer å legge til rette for trygge lceringsmiljøer og et meningsfullt innhold i en selvbestemt kroppsøvingskontekst. Mer forskning trengs for å få mer nyansert kunnskap om IBKRØVs påvirkning på elevenes motivasjon, lering og utvikling gjennom ungdomsårene.

Nøkkelord: idrettsglede, bevegelsesglede, motivasjon, interessebasert kroppsøving, autonomi, sosial tilhørighet, kompetanse

\section{Interest-based physical education}

\begin{abstract}
Research suggests that some students do not perceive the current physical education system as meaningful, and to them, the prevailing sports discourse in physical education could be counterproductive (Säfvenbom, Haugen \& Bulie, 2015). There is little knowledge on how different forms of organisation can make physical education more meaningful for students. This study uses qualitative
\end{abstract}


interviews with five pupils and a focus group of four teachers to examine how students experience physical education, and their motivation for physical education, when they participate in a new organisational model known as "interestbased physical education" (IBPE). In IBPE, students may choose between either "joy of sport" or "joy of movement". Students work towards the same competence goals in both models, but their approach will be different. Joy of movement has a playful approach to activity while joy of sport focuses more on sports development. The main idea of IBPE is that students may choose a model of physical education that accords with their own experiences, values and interests. In the current study, IBPE appears to facilitate autonomous motivation and create a learning environment where students experience a meaningful content in a safe and supportive context. Although the present results are encouraging, there is still a need for more research on the potential of IBPE to influence pupils' motivation for and development in physical education.

Keywords: joy of sports, joy of movement, motivation, interest-based physical education, autonomy, relatedness, competence

\section{Innledning}

Kroppsøvingsfaget er obligatorisk i skolen i Norge og de fleste land i verden (Hardman \& Marshall, 2000). Formålet med kroppsøvingsfaget er å inspirere til livslang bevegelsesglede og fremme positiv selvforståelse og kroppsoppfatning (Utdanningsdirektoratet, 2015). Skal formålet nås, er det av stor betydning at faget presenteres på en slik måte at barn og unge får et godt forhold til fysisk aktivitet og egen kropp. Mange elever er positivt innstilt til kroppsøving. Faget treffer spesielt godt elever som deltar i organisert konkurranseidrett på fritiden. De liker innholdet i faget og kommer godt overens med kroppsøvingslæreren (Christiansen, 2010; Flagestad \& Skisland, 2002, 2009; Mjaavatn \& Skisland, 2003; Säfvenbom et al., 2015). På den annen side finnes det også indikasjoner på at faget slik det presenteres i dag, ikke treffer alle. For noen virker faget mot sin hensikt, særlig blant de som ikke deltar i organisert konkurranseidrett på fritiden, og spesielt blant jentene i denne gruppa (Säfvenbom et al., 2015). Studier viser også at elever som ikke trives i kroppsøvingsfaget, ikke er fornøyde med aktivitetsinnholdet og ikke kommer så godt overens med kroppsøvingslæreren (Christiansen, 2010; Flagestad \& Skisland, 2002, 2009). Säfvenbom m.fl. (2015) antyder at faget i stor grad er påvirket av den rådende sportsdiskursen og treffer best de som har mest erfaring med idrett. Ifølge Annerstedt (2001) kan sportsdiskursen gjenspeile den påvirkning idretten har hatt på fagets innhold gjennom mange år. Crum (1993) påpeker at dette kan ses som en selvforsterkende sirkel. De som utdanner seg til kroppsøvingslærere, er i mange tilfeller tidligere 
idrettsflinke elever med interesse for idrett, og som lærere har de lettest for å henvende seg til de idrettsflinke elevene.

Lærerutdanningene har blitt kritisert for å opprettholde det tradisjonelle idrettsfokuset framfor å utvikle refleksjon og et kritisk blikk på undervisningspraksis blant studentene (Moen, 2011). Som et resultat av den dominerende sportsdiskursen understreker Walseth, Aartun og Engelsrud (2017) guttenes dominans i timene, og at jentene ønsker seg et annerledes fag mer i tråd med fitnessdiskursen. De trekker fram utfordringer i forhold til hvordan dette påvirker jentenes identitetsdanning. Videre kritiserer Kirk (2013) kroppsøvingsfaget for å være en multiaktivitetsmodell som skal passe alle, hvor fokus settes på terping av teknikker fra et utvalg idrettsaktiviteter elevene blir introdusert for. Faget blir også kritisert for å være et aktivitetsfag framfor et tydelig læringsfag (Annerstedt, 2007, 2008). I et forsøk på å imøtekomme utfordringene med faget ble det i 2012 gjort endringer i læreplanen for kroppsøving (Utdanningsdirektoratet, 2012). Endringene innebar blant annet tydeligere formål og kompetansemål, økt fokus på spiralprinsippet for å sikre progresjon i kompleksitet, og at innsats ble innført som del av vurderingsgrunnlaget. Det ble videre satt større fokus på å øve på idrettslige ferdigheter framfor å prestere, da øving anses som en vesentlig del av kompetansen.

Gjennom ungdomsårene ses et økende frafall fra organisert idrett (Seippel, Sletten \& Strandbu, 2011) og økende mistrivsel i kroppsøving (Säfvenbom et al., 2015). Det kan synes som om interessen for fysisk aktivitet er fallende gjennom ungdomsårene (Ommundsen \& Kvalo, 2007; Säfvenbom et al., 2015), samtidig som de unges forståelse av kropp og helse ser ut til være mer knyttet til stress enn tidligere (Nordtug \& Engelsrud, 2016). I et folkehelseperspektiv anses det som viktig å få større fokus på fysisk aktivitet og flere timer kroppsøving i skolen (Departementene, 2015). Ifølge Säfvenbom m.fl. (2015) har faget et forbedringspotensial, spesielt når det gjelder å redusere misforholdet mellom hva elevene ønsker, og hva de møter i faget. Før mer kroppsøving innføres, er det behov for mer kunnskap om tiltak, intervensjoner og prosjekter med sikte på å optimalisere relasjonen mellom elevene og kroppsøvingsfaget.

Et slikt prosjekt, kalt interessebasert kroppsøving (IBKRØV), ble gjennomført som et FoU-prosjekt ved en videregående skole i Østfold i skoleåret 2011/12. IBKRØV er en organiseringsform som lar elevene få velge mellom to varianter av kroppsøving: idrettsglede og bevegelsesglede. Begge variantene arbeider mot de samme kompetansemålene i ordinær læreplan, men tilnærmingsmåten er ulik. Bevegelsesglede fokuserer mest på en lekende tilnærming til fysisk aktivitet, med stor variasjon av alternative bevegelsesaktiviteter, tradisjonelle idretter og friluftsliv. Eleven lærer ulike treningsmetoder og varianter med fokus på utvikling av egen kropp og helse. Idrettsglede fokuserer mest på fysisk aktivitet i et idrettsperspektiv, hvor treningsmetoder og aktiviteter legges opp med tanke på idrettslig utvikling. Undervisningen gjennomføres som små emnekurs innen de ulike idrettene. Eleven lærer også om alternative bevegelsesaktiviteter og friluftsliv. 
Modellen krever at det blir gitt tydelig informasjon om innholdet i de to variantene for å sikre at elevene velger den varianten som er rett for hver av dem.

Prosjektet ble gjennomført som en kontrollert studie der utvikling av blant annet trivsel, aktivitetsnivå og motivasjon blant elevene i prosjektgruppa ble sammenlignet med en kontrollgruppe som hadde ordinær kroppsøving. Studien dokumenterte økt trivsel i kroppsøving og økt fysisk aktivitetsnivå på fritiden i prosjektgruppa (Husebye, 2012). I tillegg dokumenterte studien en signifikant positiv endring i autonom motivasjon for deltakelse i kroppsøving. Prosjektet kunne imidlertid ikke forklare hvordan den enkelte eleven erfarte IBKRØV, noe vi nå har sett nærmere på ved å intervjue elever og lærere fra den videregående skolen som deltok i prosjektet. Med utgangspunkt i elev- og lærerintervjuene undersøker vi i denne studien hvordan elever uttrykker seg om kroppsøving og egen motivasjon når de får mulighet til å velge mellom variantene bevegelsesglede og idrettsglede i IBKRØV.

\section{Selvbestemmelsesteorien og kroppsøving}

IBKRØV er utviklet med utgangspunkt i selvbestemmelsesteorien (Ryan \& Deci, 2017), som ofte blir benyttet som teoretisk rammeverk for å forstå motivasjon og hvilke faktorer som påvirker motivasjon i kroppsøving (Ryan \& Deci, 2017; Van den Berghe, Vansteenkiste, Cardon, Kirk \& Haerens, 2014). I selvbestemmelseteorien går det et viktig skille mellom autonom og kontrollert motivasjon. Autonom motivasjon for kroppsøving innebærer at elevene opplever at de deltar av egen vilje, og at de personlig kan verdsette og identifisere seg med aktivitetene. I motsetning til dette innebærer kontrollert motivasjon at elevene føler seg presset til å delta i kroppsøving. Dette presset kan være fra ytre kilder som karakterer eller straff og belønning fra lærer, men det kan også komme av indre årsaker som dårlig samvittighet eller ønske om anerkjennelse hos andre. I kontrast til både autonom og kontrollert motivasjon står amotivasjon. Amotivasjon betyr at elever mangler intensjon og motivasjon for å delta i kroppsøving. Amotivasjon kan også innebære at elever ikke føler at de har ferdighetene som forventes, eller at aktivitene ikke betyr noe for dem (Ryan \& Deci, 2017). Flere internasjonale og nasjonale undersøkelser viser at autonom motivasjon, i motsetning til kontrollert motivasjon, i kroppsøving er assosiert med flere fordelaktige utfall, som høyere aktivitetsnivå i kroppsøvingstimer, mer fysisk aktivitet på fritiden, bedre karakterer, høyere deltakelse og flere positive psykososiale utfallsmål (f.eks. Bagøien, Halvari \& Nesheim, 2010; Barkoukis, Taylor, Chanal \& Ntoumanis, 2014; Cox, Duncheon \& McDavid, 2009; Lagestad, 2017; Lonsdale, Sabiston, Raedeke, Ha \& Sum, 2009; Van den Berghe et al., 2014).

Ifølge selvbestemmelsesteorien blir autonom motivasjon i kroppsøving utviklet eller opprettholdt ved at elevene opplever at de tre grunnleggende psykologiske behovene for autonomi, kompetanse og sosial tilhørighet blir støttet og tilfredsstilt i faget. Ifølge Ryan og Deci (2017) omhandler autonomi individets behov for selvorganisering av egne opplevelser og atferd i henhold til ens integrerte 
selvoppfatning. Behovet for kompetanse beskrives som individets behov for å føle seg effektiv og oppleve mestring i interaksjon med omverdenen. Behovet for sosial tilhørighet betegnes som individets behov for å føle tilknytning til andre (Ryan \& Deci, 2017). En rekke studier innenfor kroppsøving har funnet støtte for sammenhengene mellom et behovsstøttende miljø skapt av læreren, elevenes opplevde behovstilfredsstillelse og deres autonome motivasjon (f.eks. Ntoumanis \& Standage, 2009; Standage, Duda \& Ntoumanis, 2005; Ulstad, Halvari, Sørebø \& Deci, 2018).

Som nevnt tidligere, er det i ungdomstiden stort frafall i organisert idrett og synkende interesse for fysisk aktivitet. Denne trenden er parallell med en nedgang i mer autonome former for motivasjon i kroppsøving (Ntoumanis, Barkoukis \& Thøgersen-Ntoumani, 2009). Det er derfor et behov for å utvikle modeller i kroppsøving som kan være med og fremme autonom motivasjon blant elevene.

\section{Materiale og metode}

Prosjektet denne studien baseres på, var en kontrollert studie gjennomført på en videregående skole hvor prosjektklassene gjennomførte IBKRØV, som innebærer at elevene ( $\mathrm{N}=35$ hvorav 27 jenter og 8 gutter) fikk velge mellom to varianter av kroppsøving: «idrettsglede» og «bevegelsesglede». Kontrollklassene ( $\mathrm{N}=23$ hvorav 17 jenter og 6 gutter) gjennomførte ordinær kroppsøving på samme skole. Som forklart tidligere, ga de kvantitative undersøkelsene oss noen interessante funn (Husebye, 2012), spesielt en positiv endring i motivasjon, som vi fant interessant å få større innsikt i. Kvalitative forskningsintervjuer (Kvale, Brinkmann, Anderssen \& Rygge, 2015) med elever og fokusgruppeintervjuer med lærere involvert i prosjektet, ble valgt som framgangsmåte for å belyse hvordan elever uttrykker seg om kroppsøving og egen motivasjon når de får mulighet til å velge mellom variantene bevegelsesglede og idrettsglede. Elevintervjuer ble valgt for å fange elevenes erfaringer med IBKRØV og er studiens primærkilde til informasjon. Et supplerende fokusgruppeintervju av lærerne ble også gjennomført, da vi anså det som verdifullt for å få et mer helhetlig bilde av elevenes erfaringer. Informantenes egne beskrivelser av spesielle betydninger vedrørende IBKRØV står sentralt i denne studien (Kvale et al., 2015).

\section{Utvalg}

$\mathrm{Ni}$ informanter ble strategisk valgt ut: tre elever fra bevegelsesglede (tre jenter), to elever fra idrettsglede (en gutt og en jente) og fire kroppsøvingslærere (to kvinner og to menn). Rekruttering til intervjuene foregikk gjennom e-post og telefonkontakt med seksjonslederen for kroppsøving på skolen. Elevutvalget besto av elever på videregående trinn 1 (Vg1). I denne studien er motivasjon relatert til deltakelse i undervisningen og lærernes oppfatning av elevens relasjon til faget. Det ble viktig for oss å intervjue elever med ulikt utgangspunkt i 
motivasjon for å få en nyansert forståelse av hvordan elevene uttrykker seg om IBKRØV. I samråd med seksjonsleder spurte vi tre elever som ga uttrykk for å være amotiverte for kroppsøving ved skolestart, og som hadde hatt lav deltakelse i faget på ungdomsskolen. Vi spurte også to elever som ga uttrykk for å være autonomt motivert for faget ved skolestart og hadde hatt høy deltakelse på ungdomsskolen. De tre elevene som ga uttrykk for amotivasjon ved skolestart, utgjør vårt utvalg fra bevegelsesglede. De to elevene som ga uttrykk for autonom motivasjon ved skolestart, utgjør vårt utvalg fra idrettsglede. Det var viktig for studiens validitet at elever fra både bevegelsesglede og idrettsglede ble intervjuet. Lærerutvalget besto av tre kroppsøvingslærere og en fagleder, som alle hadde undervisning med elevene i IBKRØV. Fagleder var omtrent like mye innom begge varianter, to av lærerne mest i bevegelsesglede og én lærer mest i idrettsglede. Vi ønsket å intervjue lærerne som underviste elevene i IBKRØV med håp om å oppnå en bredere forståelse av alle elevenes motivasjon sett fra lærernes perspektiv.

\section{Intervjuguide og etikk}

For å skape struktur i intervjuforløpet (Kvale et al., 2015) ble intervjuene gjennomført med utgangspunkt i to intervjuguider, én for elevene og én for lærerne (se vedlegg). For å belyse tematikken og skape en god dynamikk med informantene ble spørsmålene utformet så åpne som mulig. Dette skulle gi oss rike og nyanserte beskrivelser av deres erfaringer med IBKRØV (Kvale et al., 2015). Både elevintervjuene og fokusgruppeintervjuet med lærerne ble gjennomført på et grupperom på skolen. Intervjuene ble ledet av en av forfatterne og varte fra 15 til 60 minutter. Gjennomføring av intervjuene fulgte etiske retningslinjer for kvalitativ forskning (Creswell, 2013). Samtlige informanter ga et informert og frivillig samtykke til deltakelse, i tråd med personopplysningsloven (Justis- og beredskapsdepartementet, 2000). Studien er meldt til og godkjent av Norsk senter for forskningsdata og behandler ikke direkte personopplysninger. Konfidensialitet er ivaretatt ved at dataene kun er tilgjengelige for forskerne i studien på passordbeskyttede PC-er, og lydfilene ble destruert etter transkribering (Justis- og beredskapsdepartementet, 2000). Vi har gitt elevene fiktive navn, fra idrettsglede Alba (IG) og Birk (IG), og fra bevegelsesglede Christin (BG), Dina (BG) og Eline (BG).

\section{Bearbeiding, analyse og tolkning}

Intervjuene ble tatt opp på digital lydfil, ordrett transkribert og klargjort for analyse. Creswell (2014) sin prosedyre for kvalitativ analyse av materialet fra både elevintervjuene og fokusgruppeintervjuet ble brukt som utgangspunkt. Da vi er to forfattere, startet vi med å lese gjennom alt materialet hver for oss for å danne oss et selvstendig førsteinntrykk av informantenes erfaringer, før vi leste gjennom alt materialet sammen. Vi ble enige om først å sortere innholdet etter hovedtemaene i intervjuguiden, som var autonomi, tilhørighet og kompetanse, for 
deretter å kode betydningsfulle uttalelser om hvordan elevene uttrykte seg om kroppsøving og egen motivasjon (Creswell, 2014). Lærernes uttalelser ble sortert etter samme koder, og supplerte elevenes uttalelser. Eksempler på koder: opplevelser, mestring, medbestemmelse, miljø, venners betydning, sett av lærer. Uttalelser med sammenfallende mening ble igjen gruppert i større temaer: elevens historie med kroppsøvingsfaget, valget og meningsfulle aktiviteter, kompetanse og læring, og trygghet og sosialt miljø. Disse temaene utgjør overskriftene i resultatkapitlet og diskusjonskapitlet. Den fortolkende prosessen ble gjennomført av begge forfatterne slik at vi kunne diskutere og skape meningsforståelse i fellesskap. Vi har i stor grad benyttet de intervjuedes stemmer, gjennom sitater, for å formidle intervjupersonenes meninger i resultatene fra intervjuene.

\section{Metodiske svakheter}

Vårt utgangspunkt for å gjennomføre studien var egne erfaringer og interessante funn fra førstegangsutprøving av IBKRØV (Husebye, 2012). Dette kan ha bidratt til at vår forståelse ble farget, ved at vi i utgangspunktet hadde en førforståelse om at elevene hadde positive erfaringer med modellen. Dette kan ha svekket undersøkelsens validitet (Creswell, 2014). Resultat og drøfting må leses med forsiktighet, da utvalget av elever fra hver variant er lite og ubalansert med tanke på kjønn (én gutt, fire jenter) og fordeling på variant (tre fra bevegelsesglede, to fra idrettsglede). Ifølge Walseth m.fl. (2017) kan det finnes kjønnsmessige forskjeller med hensyn til hvordan gutter og jenter opplever kroppsøving. Dermed kunne resultatene våre vært annerledes med en annen kjønnsfordeling. På grunn av det lille utvalget gikk vi glipp av verdifulle nyanser og erfaringer og oppnådde ikke total informasjonsmetning (Kvale et al., 2015) hva gjelder erfaringer med modellen. Innenfor undersøkelsens begrensede rammer gir resultatene likevel tilgang til uttrykte erfaringer med modellen i begge varianter fra ulike kilder, både elever og involverte lærere. Denne formen for triangulering anses som styrkende for resultatenes pålitelighet og validitet (Creswell, 2014). Vi kan ikke med sikkerhet si at vårt utvalg representerer de andre elevenes motivasjonsprofil $\mathrm{i}$ samme variant. For eksempel ble bevegelsesglede bare belyst fra elever med tidligere dårlige erfaringer med kroppsøving. Det hadde også vært interessant å fange erfaringer fra elever som i utgangspunktet var motivert til kroppsøving, både de som fortsatte å være motivert, og de som eventuelt ble mindre motivert etter gjennomføring av bevegelsesglede. Det var ifølge seksjonsleder få elever som beveget seg mot amotivasjon, og det var utfordrende å få tak i disse. Fokus i intervjusamtalen med lærerne var i stor grad rettet mot elever med tidligere negativ historikk i faget, og vi ser i etterkant at det ville vært en styrke for studiens validitet om vi hadde hatt fokus på flere motivasjonsprofiler. 


\section{Resultater}

\section{Elevenes historie med kroppsøvingsfaget}

Alba (IG) gir inntrykk av å være trygg på seg selv og gir tydelige svar på spørsmålene. Hun er glad i idrett og har alltid vært motivert og aktiv i timene.

Det har vært favorittfaget, fordi jeg liker å vise meg litt fram på en måte, og fordi jeg synes jeg gjør det litt bra. Jeg er jo ganske bra i ballspill og sånn.

På ungdomsskolen fikk hun gode karakterer i faget. Hun synes faget har løftet seg til å bli enda bedre på Vg1, og trekker spesielt fram lærerens kompetanse.

Birk (IG) virker litt usikker og gir korte svar. Han har alltid vært glad i kroppsøving og deltatt i stor grad, men føler at faget han har møtt på Vg1 har truffet han bedre enn på ungdomskolen.

Jeg liker gym bedre her, fordi vi bruker mer tid på hver gren. Jeg liker å gjøre mye forskjellig innenfor en sport. Da ser jeg forbedringen.

Christin (BG) trekker begge bena opp i stolen under intervjuet, men er likevel trygg når hun svarer. Hun oppfatter seg ikke som en idrettstype, men har begynt å svømme nå. Hun har mindre gode opplevelser med faget fra ungdomsskolen, men nå gleder hun seg til kroppsøvingstimene.

Før hadde jeg prestasjonsangst når guttene var veldig konkurranseinnstilte. Da ville jeg ikke møte i gymmen, men nå er miljøet veldig bra. Nå er det annerledes. Nå vil jeg ha gym flere ganger i uka.

Dina (BG) tenker seg veldig godt om før hun svarer, og kommer med lange svar. Hun har vært aktiv danser, men har sluttet med det nå. Hun sier hun ikke har «sånn superferdigheter i gym», men gjør så godt hun kan. På ungdomsskolen glemte hun ofte gymtøy eller utførte «slække-gym» som ifølge henne selv var «å kanskje gi på litt ekstra når læreren så deg, jeg var ikke veldig aktiv». Nå ønsker hun å stå på mye mer, for hun forstår at det er noe hun kan gjøre for å få bedre karakter.

Eline (BG) gir lange og reflekterte svar. Hun oppfatter seg selv som svak i kroppsøving. På ungdomsskolen gruet hun seg til kroppsøving på grunn av miljøet og manglende tro på utvikling og framgang. På Vg1 gleder hun seg mer til undervisningen og deltar i større grad enn på ungdomsskolen.

Lærerne virker som et samkjørt team, der seksjonsleder er mest framtredende i sine svar. Lærerne har en oppfatning om at kroppsøvingsfaget i ungdomskolen har vært preget av idrettens verdier, og sier «for mange er det verdifullt, men det er viktig også å favne de som idretten ikke når». På dette området mener lærerne de har lykkes. Flere av elevene som ikke er opptatt av idrett, er nå mer aktive i timene. 


\section{Valget og meningsfulle aktiviteter}

Alle elevene er fornøyde med å kunne velge variant. Alba (IG) var veldig sikker på at hun skulle velge idrettsglede.

Jeg syns det er veldig bra å få velge, fordi det er selvfølgelig noen som bare vil leke og noen som vil ta det mer seriøst. Jeg vil ta det veldig seriøst. Jeg synes alle burde ha mulighet til å velge, for det er ikke alle som kan prestere like mye. De kan ta bevegelsesglede. De som føler de kan prestere mye kan ta idrettsglede.

Alba (IG), Eline (BG) og Birk (IG) anbefaler andre skoler å legge opp til IBKRØV. Alba (IG) sier hun vil prestere mer når hun får velge. Birk (IG) synes også det er bra å kunne velge, for han mener noen er slappere enn andre, og at de derfor bør velge bevegelsesglede, mens de som vil ha mindre lek, mer sport og større innsats, bør velge idrettsglede. Christin (BG) var usikker før valget.

Først var jeg innstilt på å velge idrettsglede, for nå skulle jeg bli mer sporty, men så tenkte jeg, hvis jeg ikke føler jeg mestrer det, så er det ikke gøy. Jeg må velge noe jeg kan mestre og ha det gøy i. Da blir jeg mer motivert.

\section{Christin (BG) mener skolen bør fortsette med IBKRØV.}

Det er viktig å føle du kan ha påvirkning i faget. Det er viktig i flere fag, å få være med å bestemme.

Dina (BG) hadde tenkt å velge idrettsglede, men syntes aktivitetene passet henne bedre på bevegelsesglede.

Idrett er mer sånn hvis du har trent en del fra før, tror jeg, litt hardere trening, mer krevende, mens bevegelsesglede er masse forskjellig, at vi skal få en smakebit og kanskje interessere oss for noe.

Dina (BG) synes det er bra å få lov til å velge.

Det er bra du kan få litt å si selv, som hvis du ikke interesserer deg for det ene, så kan du velge det andre.

Eline (BG) mener undervisningen gir mer utbytte når hun kan velge, fordi den ikke blir så tvunget.

Bevegelsesglede er mer for de som vil gjøre litt forskjellig, som ikke er så veldig teknisk. Du kanskje har det mer for gøy, holdt jeg på å si. Jeg føler de som ikke tar idrett så alvorlig, har tatt bevegelsesglede. De som tar idrett, får kanskje utviklet seg mere, hvis de liker sport og sånn.

Nå kan hun velge bort det som minner henne mest om faget på ungdomsskolen, som hun erfarte som ubehagelig, mye på grunn av opplevelsen av å bli stilt ut foran de andre. Eline (BG) mener hun har blitt sikrere på seg selv gjennom IBKRØV. Seksjonsleder tror elever som søker mot et prestasjons- og 
konkurransefokus, velger idrettsglede, og de som ønsker mindre fokus på tekniske prestasjoner, velger bevegelsesglede.

\begin{abstract}
Elevene melder de har høyere trivsel i faget når de får lov til å velge, og får slippe prestasjonspresset. Elever som ikke har med seg gode erfaringer fra gym på ungdomsskolen, og som aldri har opplevd noe særlig mestring med fysisk aktivitet, nettopp på grunn av at fokuset har vært på idrettslige prestasjoner, de får nå positive opplevelser med fysisk aktivitet for første gang. Som elever har sagt: jeg kan faktisk være i aktivitet bare for min egen skyld, jeg må ikke springe fort sammenlignet med andre, det tror jeg er en ny opplevelse for mange, og gir noen elever en ny dimensjon av fysisk aktivitet.
\end{abstract}

Ifølge lærerne velger de fleste elevene bevegelsesglede, og prosentvis fordeling er rundt 70-30, noe som førte til at skoleledelsen valgte å sette inn ekstra ressurser slik at lærertettheten økte i den største gruppa. Seksjonsleder antar denne skjevfordelingen skyldes at mange har opplevd idrettsperspektivet som truende for deres eget selvbilde gjennom kroppsøving i grunnskolen.

Det å være i en gruppe som har et mer likt forhold til idrett og fysisk prestasjon, har en positiv innvirkning på elevenes motivasjon.

Alba (IG) sier at kroppsøving for hennes del bør være seriøst og ha fokus på idrettslig utvikling. Hun trekker spesielt fram lærerens kompetanse som positivt.

Gymlæreren vi har, han kan alt liksom. Han er positiv til alle sammen. Han presser ikke for mye, men dytter oss videre.

Birk (IG) mener også læreren er flink fordi han «viser ting, og viser ting bra, han viser alt». Selv om lærer bruker god tid på hvert emne, opplever Birk (IG) undervisningen som variert. Birk (IG) kunne gjerne brukt enda mer tid på hver gren, for å se ytterligere framgang. Christin (BG) og Dina (BG) liker at undervisningen er variert, og nevner noen aktiviteter: «Vi har yoga, klatring, spinning, styrke, stiv heks, håndball, hjørnefotball og sånne ting.» Christin (BG) synes det er bra at læreren deltar aktivt. Dina (BG) har god relasjon til læreren og vil ha det gøy i timene med lek og spill og mindre fokus på teknikker og plasseringer, slik de hadde på ungdomsskolen.

Når vi hadde håndball, det er kanskje det verste jeg veit, å gå gjennom alle disse plassene og du skal være der og gjøre sånn og sånn, istedenfor å ha det litt gøy for oss som ikke kan det. Alle er ikke håndballjenter som får til alt, og som er stjerneelever uansett. Vi var lissom slækkegjengen fordi vi ikke var noe flinke i sporter, og da gidder du ikke gjøre så mye innsats heller. Du må være glad i de tingene du skal gjøre for at de skal være motiverende.

Lærerne sier det utføres mer instruksjon og holdes lengre kurs innenfor ulike idretter og aktiviteter i idrettsglede. Da kan elevene terpe mer teknikk og utvikle sine idrettslige ferdigheter. 
Hvis vi har volleyball, vil idrettsglede ha volleyball i 4-6 uker, mens bevegelsesglede i samme periode vil ha 1 uke volleyball og deretter lek og ulike spillvarianter av volleyball og andre nettspill. Elevene vil utvikle sine bevegelsesferdigheter uten å tenke at det er målet.

Lærerne trekker også fram viktigheten av å se hver enkelt elev og tilpasse opplæringen ut fra elevens forutsetninger.

Kroppsøving, som alt annet, må være meningsfullt for eleven, og for noen er det ikke meningsfullt å forbedre konkrete idrettslige ferdigheter.

\section{Kompetanse og læring}

Vi finner at flere av elevene nå motiveres av muligheten til å få bedre karakter. Både Dina (BG) og Eline (BG) ser hvilken betydning egen innsats har på karakteren. På Vg1 har de opplevd at alle kan få en god karakter selv om de ikke er idrettslig flinke i kroppsøving. Dina (BG) sier:

Før tenkte jeg at jeg ikke har anlegg for det eller er en gymperson, men nå tenker jeg det har ikke med det å gjøre. Alle kan få en bra karakter i gym uavhengig av hvilke ferdigheter du har, hvis du prøver. Det er kult. Mamma fikk sjokk, det var ikke noe hun kunne sett for seg at jeg skulle fått 5 i gym, de blir jo stolte av meg. Da blir jeg glad. Trenger at noen er stolte av meg.

På ungdomsskolen følte Eline (BG) at hun ble plassert i en karakter fra første stund, og at det var umulig for henne å få utvikling i faget.

Og så var det liksom de som var flinke, DE var flinke, og de andre holdt seg mer i bakgrunnen. Det var såpass stor klasse, og de flinke trengte seg liksom på. Gjorde du noe bra, så følte du ikke du ble sett. Du kunne stå på så mye du ville, men læreren så deg virkelig ikke. Jeg gledet meg ikke, for jeg følte jeg ikke fikk noe særlig ut av det uansett om jeg sto på eller ei. Nå blir jeg mer sett. Det er litt mindre grupper. Det er tre på hvert lag, og da føler du det er litt mer behov for deg. Da må du ha mer innsats. For eksempel når det er ballspill, må jeg stå på mer for at det skal bli ordentlig spill i laget. Nå føler jeg at jeg har en rolle i klassen, så jeg kommer litt mer ut på banen.

Ifølge lærerne virker det som om flere elever er fornøyde med at innsats skal vektlegges i vurderingen, i tråd med ny læreplan.

\section{Trygghet og sosialt miljø}

Alba (IG) er fornøyd med miljøet i idrettsglede, men blir irritert når de andre i gruppa ikke gidder å stå på. «Da kunne de valgt bevegelsesglede,» sier hun. Birk (IG) synes det er bra miljø fordi alle blir inkludert, selv om han er eneste gutt fra sin klasse som valgte idrettsglede. Både Christin (BG) og Eline (BG) vektlegger det gode miljøet i bevegelsesglede for deres deltakelse i faget, og mener miljøet har forandret seg fra å være ubehagelig og preget av prestasjonsfokus, til å bli trygt, aksepterende og inkluderende. «Det gjør ikke noe å drite seg ut, og da er det mye morsommere,» sier Christin (BG). Eline (BG) sier: 
Du er ikke redd for å løpe og misse ballen eller noe sånt. Sånn var det før, du torde ikke fordi du trodde at folk kom til å le nesten, og så var det sånn ubehagelig for da skulle alle se du stupte kråke og sånn.

Dina (BG) trives og sier: «Alle er ikke bestevenner, men alle kan prate sammen.» Læringsmiljøet i prosjektgruppene er ifølge lærerne bra og deltakelsen svært høy sammenlignet med hva lærerne har erfart tidligere. De fokuserer på å skape godt samhold og inspirere til innsats i begynnelsen av skoleåret. Målet er at elevene skal gå fra timen med en god opplevelse.

\section{Diskusjon}

Resultatene i denne studien har blitt presentert i fire hovedkategorier: 1) Elevenes historie med kroppsøvingsfaget, 2) Valget og meningsfulle aktiviteter, 3) Kompetanse og læring, og til sist 4) Trygghet og sosialt miljø. Disse funnene blir i de følgende avsnittene tolket og analysert opp mot tidligere studier og relevant litteratur.

\section{Elevenes historie med kroppsøvingsfaget}

Flere av de erfaringene som trekkes fram av elevene, handler om idrett, idrettslig kompetanse og prestasjon, noe som ikke er uvanlig for kroppsøvingsfaget (Larsson \& Redelius, 2008). Bevegelsesgledeelevene uttaler en samstemt karakteristikk av å ikke være flinke eller ha idrettslige ferdigheter. Deres uttalelser om sine historier med kroppsøvingsfaget sammenfaller med andre studier som hevder at sportsdiskursen er rådende innen faget (Säfvenbom et al., 2015; Walseth et al., 2017). Det er interessant å se hvordan elevene konstruerer sin forståelse av kompetanse i kroppsøvingsfaget. Idrettsgledeelevene oppfattes som de med høyest kompetanse i faget, og denne kompetansen relateres til idrettslige ferdigheter og prestasjoner. En mulig årsak kan finnes i idrettens mangeårige påvirkning på faget (Annerstedt, 2001; Säfvenbom, 2010) og utdanningssystemets opprettholdelse av dette fokuset (Crum, 1993; Moen, 2011), noe som kan skape et misforhold mellom kroppsøvingsfagets formål og elevenes oppfatning av fagets mål (Utdanningsdirektoratet, 2015). I denne studien kan det se ut som om den rådende sportsdiskursen og fokus på idrettslig prestasjon over tid har medført en selvforståelse blant bevegelsesgledeelevene av ikke å ha de ferdighetene som forventes i kroppsøving. Lærerne mener også det idrettsfokuserte kroppsøvingsfaget kan være en mulig årsak til elevenes tidligere negative erfaringer med faget.

Konsekvenser av ikke å finne seg til rette i et fag i tråd med sportsdiskursen kan være flere. Ifølge Walseth m.fl. (2017) er en konsekvens at jentene ønsker seg et mer fitnessinspirert fag hvor målet er å gjøre kroppen «fit» gjennom effektiv trening. Uheldige konsekvenser av dette er den kroppsforståelsen som da får råde, ved at kroppen blir et objekt som skal formes og utstilles, og fokus flyttes bort fra kroppens potensial (ibid.). En annen konsekvens kan være utvikling av 
amotivasjon for faget som medfører manglende eller totalt fravær av deltakelse i kroppsøvingsundervisningen (Ryan \& Deci, 2017). Bevegelsesgledeelevene hadde en negativ historie med faget før Vg1, med lav til ingen deltakelse i faget. Det kan se ut som om måten kroppsøvingsfaget ble presentert på gjennom bevegelsesgledevarianten, nå har bidratt til å snu en negativ historie med faget til positive erfaringer.

\section{Valget og meningsfulle aktiviteter}

Det kan virke som om elevenes historier med faget påvirker deres forventninger til seg selv og andre elever, og utgjør grunnlaget for valg av variant. Idrettsgledeelevene forventer seriøsitet og høy innsats hos seg selv og andre. Deres forventninger til elever som velger bevegelsesglede er at de ikke kan prestere like mye og har lavere innsats. Bevegelsesgledeelevene derimot anser sin egen innsats som god, men at idrettsgledevarianten blir for krevende da de ikke er flinke nok i idrett. Slik vi tolker det, er det meningsfullt for idrettsgledeelevene at faget er i tråd med sportsdiskursen, og de blir ytterligere motivert av å kunne velge en enda mer idrettsfokusert variant av faget. Det tyder også på at de anser høy prestasjon i kroppsøvingsfaget til å være idrettsrelatert. For bevegelsesgledeelevene gir det mening å kunne velge en variant som representerer noe annet enn det tradisjonelle kroppsøvingsfaget. Lærerne mener det handler om et valg mellom et prestasjonsog konkurransefokusert fag (idrettsglede) og et fag med fravær av prestasjonspress (bevegelsesglede). Det kan se ut til at prestasjonspresset for de tre bevegelsesgledeelevene reduseres når idrettsfokuset blir borte. De slipper nå å tenke på at de ikke er flinke nok eller ikke har de ferdigheter de tror er forventet for å prestere i faget. Gjennom bevegelsesglede har de også erfart å bli mer sett, at det er rom for prøving og feiling, og at de unngår å gjemme seg bort og være det Lyngstad, Hagen og Aune (2016) kaller en «ribbeveggsløper», det vil si en elev som deltar, men uten intensjon om å være delaktig i spillet.

Gjennom IBKRØV kan elevene, uavhengig av om de liker idrett eller ikke, velge et innhold i faget som er mer i tråd med deres bevegelseserfaringer, verdier og interesser. Sett i lys av selvbestemmelsesteorien (Ryan \& Deci, 2017) er dette svært viktig da det kan bidra til å tilfredsstille elevenes behov for autonomi ved å selvorganisere egne opplevelser og atferd i tråd med ens integrerte selvoppfatning. IBKRØV kan dermed være med på å legge til rette for en kontekst hvor opplevelsen av autonomi forsterkes, og som en følge av dette kan også en positiv selvforståelse utvikles og motivasjon for kroppsøving påvirkes positivt. Det kan se ut til at elevene gjennom IBKRØV har gjort valg som har vært riktige for dem. Bevegelsesgledevarianten i IBKRØV ser ut til å være et godt alternativ for elever som ønsker seg et mindre idrettsfokusert fag, og som kan imøtekomme utfordringene med jenter som ikke finner sin plass i faget (Walseth et al., 2017).

I en tradisjonell kroppsøvingskontekst hvor elevene ikke kan velge et fag som er i tråd med sine erfaringer og interesser, kan innholdet oppleves som lite meningsfullt for en del elever (Säfvenbom et al., 2015). Alle elevene trekker fram 
at innholdet i undervisningen gjennom IBKRØV har gitt positivt utslag på deres opplevelse av mening i faget. Idrettsgledeelevene opplever det meningsfullt med fokus på teknikk og idrettslig utvikling innenfor små emnekurs. De tre elevene fra bevegelsesglede opplever det meningsfullt med mer variasjon, lekbetonte bevegelsesformer og mulighet for å velge bort det ubehagelige prestasjonspresset de tidligere har opplevd i faget.

\section{Kompetanse og læring}

Idrettsgledeelevene trekker fram at fokuset på læring har blitt større etter gjennomføringen av IBKRØV. Bevegelsesgledeelevene oppfatter ikke læring like tydelig, men heller at faget ble mer variert og lekbetont. Samtidig trekker de fram at de nå mestrer faget bedre, deltar mer og har en viktigere rolle i lagspill. Implisitt kan dette forstås som at læring har funnet sted, men elevene er kanskje ikke like bevisste på sin læring som idrettsgledeelevene. Dette bekrefter lærerne når de forklarer at bevegelsesgledeelevene utvikler ferdigheter uten å tenke at det er målet. En ubevisst læring av ferdigheter ved «å ha det gøy» kan sees på som en utfordring siden bevisstgjøring av læringsmål anses som viktig for fagets legitimering i skolen (Ommundsen, 2005, 2012) og for elevenes forståelse av faget som et læringsfag (Redelius, Quennerstedt \& Öhman, 2015). Ifølge lærerne har fokus vært på læring for begge danner ved at de har jobbet bevisst mot de samme kompetansemålene. Ut fra elevenes beretninger kan det se ut til at IBKRØV inviterer til to ulike forståelser av hva kroppsøvingsfagets mål er. Målene heller i retning av enten «å ha det gøy med aktivitet» (bevegelsesglede) eller «å lære idrettslige ferdigheter» (idrettsglede), noe som kan henge sammen med hvordan de to variantene ble presentert for elevene. Dette funnet er særlig relevant for diskusjonen rundt kroppsøvingsfaget som aktivitetsfag eller læringsfag (Annerstedt, 2007) og noe lærerne må ta høyde for ved anvendelse av IBKRØV. Uansett variant må læringsfokuset komme tydelig fram.

Gjennom IBKRØV virker det som om bevegelsesgledeelevene endrer sitt syn på hvem som kan få bra karakterer i kroppsøving, noe som henger sammen med deres egen erfaring av å oppnå bedre karakter på Vg1. De to som uttrykker å ha forbedret karakteren, forklarte at forbedringen kom som en konsekvens av mer deltakelse og større innsats. De kom mer ut på banen, tok ansvar i laget, framgang oppsto, det ble mer gøy og de opplevde å bli sett. Fokus på karakterer kan ofte oppleves som en kontrollert form for motivasjon (Ryan \& Deci, 2017). Det kan riktignok se ut til at karakterens betydning for motivasjonen har fått en annen rolle for de to jentene, ved mindre vurderingsfokus på idrettstekniske prestasjoner. Endring i vurderingsfokus, i kombinasjon med økt trivsel og deltakelse, ser ut til å bevege elevene i retning av autonom motivasjon framfor kontrollert motivasjon, når de snakker om karakterer.

Elevenes ulike fokus og interesser i de to variantene kan bidra til at elevene blir mer synlige på nye måter, og lærerne må tilpasse innhold og tilnærmingsmåte 
deretter. Dermed kan lærerne bli mer bevisste på elevenes mangfold av kompetanse, også utover idrettslig kompetanse. Lærernes bevisstgjøring rundt mangfoldet av kompetanse kan bidra til å bryte med et tradisjonelt idrettsfokusert mønster i faget og hjelpe læreren i planleggingen av undervisningen (Annerstedt, 2001; Säfvenbom et al., 2015).

\section{Trygghet og sosialt miljø}

Ifølge Ryan og Deci (2017) betegnes behovet for sosial tilhørighet som individets behov for å føle tilknytning til andre, og den sosiale konteksten kan virke enten støttende eller hemmende for elevens motivasjon i aktiviteten. Oppleves konteksten som støttende, vil eleven kunne føle sosial tilhørighet til gruppa og dermed i større grad ønske å delta og være en del av gruppa. Tilstedeværelse av elever som er svært prestasjonsfokuserte, kan forstyrre andre elevers trygghet og bevegelsesglede. Det virker som om bevegelsesgledeelevene opplevde en befrielse fra uheldige emosjoner når de prestasjonsfokuserte elevene forsvant. Samtidig uttrykte idrettsgledeelevene at de kunne ha et sterkere fokus på egen utvikling når de ikke trengte å være sammen med medelever som fokuserer mindre på idrett og prestasjon. For begge grupper kan elevenes selvoppfatning knyttet til bevegelse forsterkes. For oss virker det som om kroppsøvingskonteksten oppleves som mer støttende når det er etablert mer homogene grupper basert på interesse og prestasjonsfokus.

Kroppsøvingslærernes kompetanse og evne til å skape gode relasjoner til elevene kan bidra til å fremme en støttende kroppsøvingskontekst for elever (f.eks. Bergkastet, Dahl \& Hansen, 2009; Brattenborg \& Engebretsen, 2013). Gjennom intervjuene får vi inntrykk av at læreren har hatt en positiv betydning for elevenes motivasjon. Bevegelsesgledeelevene opplevde lærerens aktive deltakelse som positiv. Idrettsgledeelevene trakk spesielt fram lærerens kunnskap og evne til å lære eleven mye nytt. Det ser ut til at læreren i hver av variantene kan ha bidratt til autonom motivasjon ved å henholdsvis skape gode relasjoner og sette meningsbærende læring i fokus (Ommundsen, 2012).

En konsekvens av modellen kan være en skjevfordeling av gruppestørrelse, noe som skjedde i denne studien da over to tredjedeler av elevene valgte bevegelsesglede og kun to lærere var involvert. Dette påvirket lærertettheten i de ulike gruppene, og muligheten for å skape gode relasjoner med alle elevene kan være mer krevende i den største gruppa. I denne studien ble utfordringen med lærertetthet møtt ved å sette inn en ekstra lærer i den største gruppa, men rammefaktorer kan begrense denne muligheten i andre tilfeller. Det at så mange elever valgte bevegelsesglede, er i seg selv interessant, da det kan si noe om at mange elever ønsker en ny vinkling i faget, i tråd med at en del elever ikke ser meningen i faget (Säfvenbom et al., 2015). 


\section{Konklusjon}

De fem elevene i denne studien uttrykker erfaringer fra et kroppsøvingsfag med sportsdiskursen som rådende, og disse erfaringene kan ha påvirket hvordan elevene har konstruert sin forståelse av kompetanse og målet med faget. Det ser likevel ut til at elever som uttrykker å ha tidligere negative erfaringer med kroppsøving, gjennom IBKRØV kan snu de negative opplevelsene fra et prestasjonsfokusert og idrettspreget kroppsøvingsfag. Disse elevene ser ut til å konstruere nye forståelser for fagets innhold og kompetanse av betydning. Elevene har gjennom IBKRØV fătt velge et fag som de uttrykker er mer i tråd med sine verdier, interesser og bevegelseserfaringer. Bevegelsesgledeelevene uttrykker at de gjennom IBKRØV har erfart et trygt og inkluderende fag hvor de er blitt mer sett av læreren. Dette, i tillegg til å få velge variant, ser ut til å øke deres autonome motivasjon for faget. Idrettsgledeelevene uttrykker at faget har blitt bedre gjennom ytterligere fokus på idrettslig utvikling. Selv om kroppsøvingskonteksten gjennom IBKRØV erfares som mer meningsfull har læringsfokuset vært noe utydelig for bevegelsesgledeelevene. Dette er ikke tilfellet for idrettsgledeelevene. De ser ut til å øke sin autonome motivasjon for faget, spesielt på grunn av lærerens kompetanse og mulighet til mer spesialisering og mindre forstyrrelser av useriøse elever. Ved framtidig igangsetting av IBKRØV bør lærerne jobbe med elevene om bevisstgjøring av læringsmål i begge varianter slik at kroppsøving oppleves som et læringsfag. Lærerne må også bevisstgjøre elevene rundt fagets mangfold av betydningsfull kompetanse. IBKRØV kan være en mulig modell for å fremme autonom motivasjon for elevene, men med tanke på våre reservasjoner om utvalget vil det være nødvendig å prøve ut modellen i en større skala på flere skoler og på flere trinn i opplæringen, både for å kunne trekke videre konklusjoner og for få mer innsikt i modellen og dens perspektiver.

\section{Om forfatterne}

Steffen Tangen er høgskolelektor på seksjon for kroppsøving og idrett ved Høgskolen i Østfold. Hans forskningsinteresser omfatter kroppsøvingsdidaktikk og barns lek og utforsking i natur.

Institusjonstilknytning: Avdeling for lærerutdanning, Høgskolen i Østfold, Postboks 7000, 1757 Halden.

E-post: steffen.tangen@hiof.no

Birgitte Nordahl Husebye er høgskolelektor på seksjon for kroppsøving og idrett ved Høgskolen i Østfold. Hennes forskningsinteresser omfatter kroppsøvingsdidaktikk og estetiske læringsprosesser.

Institusjonstilknytning: Avdeling for lærerutdanning, Høgskolen i Østfold, Postboks 7000, 1757 Halden.

E-post: birgitte.n.husebye@hiof.no 


\section{Referanser}

Annerstedt, C. (2001). Varför undervisa i ämnet idrott och hälsa. I C. Annerstedt, B. Peitersen \& H. Rønholt (red.), Idrottsundervisning (s. 123-144). Gøteborg: Multicare förlag AB og Forlaget Hovedland.

Annerstedt, C. (2007). Att (lära sig) vara lärare i idrott och hälsa. Gøteborg: Multicare förlag $\mathrm{AB}$.

Annerstedt, C. (2008). Physical education in Scandinavia with a focus on Sweden: a comparative perspective. Physical Education and Sport Pedagogy, 13(4), 303-318.

Bagøien, T. E., Halvari, H. \& Nesheim, H. (2010). Self-determined motivation in physical education and its links to motivation for leisure-time physical activity, physical activity, and well-being in general. Perceptual and Motor Skills, 111(2), 407-432.

Barkoukis, V., Taylor, I., Chanal, J. \& Ntoumanis, N. (2014). The relation between student motivation and student grades in physical education: A 3-year investigation. Scandinavian Journal of Medicine \& Science in Sports, 24(5), 406-414.

Bergkastet, I., Dahl, L. \& Hansen, K. A. (2009). Elevenes læringsmiljø-læererens muligheter: en praktisk håndbok i relasjonsorientert klasseledelse. Oslo: Universitetsforlaget.

Brattenborg, S. \& Engebretsen, B. (2013). Innføring i kroppsøvingsdidaktikk (3. utg.). Oslo: Cappelen Damm akademisk.

Christiansen, K. (2010). Elevers tanker om kroppsøvingsfaget. Kroppsøving, 3, 8-11.

Cox, A. E., Duncheon, N. \& McDavid, L. (2009). Peers and teachers as sources of relatedness perceptions, motivation, and affective responses in physical education. Research Quarterly for Exercise and Sport, 80(4), 765-773.

Creswell, J. W. (2013). Qualitative inquiry \& research design: choosing among five approaches (3. utg.). Los Angeles: Sage.

Creswell, J. W. (2014). Research design: qualitative, quantitative, and mixed methods approaches (4. utg.). Los Angeles: Sage.

Crum, B. J. (1993). Conventional Thought and Practice in Physical Education: Problems of Teaching and Implications for Change. Quest, 45(3), 339-356.

Departementene (2015). Folkehelsemeldingen - mestring og muligheter. Meld. St. 19 (20142015). Oslo: Departementenes servicesenter.

Flagestad, L. \& Skisland, J. O. (2002). Årsaker til mistrivsel i kroppsøving. Kroppsøving, 4, 21-26.

Flagestad, L. \& Skisland, J. O. (2009). Økt trivsel i kroppsøvingsfaget. I B. J. Fjeld (red.), Nyere perspektiv innen idrett og idrettspedagogikk (s. 195-199). Kristiansand: Høgskoleforlaget.

Hardman, K. \& Marshall, J. (2000). Update on the State and Status of Physical Education World-wide. International Council of Sport Science and Physical Education. Hentet fra:

https://www.icsspe.org/sites/default/files/Ken\%20Hardman\%20and\%20Joe\%20Marsh all-\%20Update\%20on\%20the\%20state\%20and\%20status\%20of\%20physical\%20educ ation\%20world-wide.pdf

Husebye, B. (2012). Bevegelsesglede I. Østfold fylkeskommune.

Justis- og beredskapsdepartementet (2000). Lov om behandling av personopplysninger (personopplysningsloven). Hentet fra: https://lovdata.no/dokument/LTI/lov/2000-0414-31

Kirk, D. (2013). Educational Value and Models-Based Practice in Physical Education. Educational Philosophy and Theory, 45(9), 973-986. 
Kvale, S., Brinkmann, S., Anderssen, T. M. \& Rygge, J. (2015). Det kvalitative forskningsintervju (3. utg., 2. oppl.). Oslo: Gyldendal akademisk.

Lagestad, P. (2017). Å velge aktiviteter selv som grunnlag for trivsel og mestring. En casestudie i kroppsøvingsundervisningen ved en videregående skole. Acta Didactica Norge, 11(2), Art. 4.

Larsson, H. \& Redelius, K. (2008). Swedish physical education research questioned-current situation and future directions. Physical Education and Sport Pedagogy, 13(4), 381398.

Lonsdale, C., Sabiston, C. M., Raedeke, T. D., Ha, A. S. C. \& Sum, R. K. W. (2009). Selfdetermined motivation and students' physical activity during structured physical education lessons and free choice periods. Preventive Medicine, 48(1), 69-73.

Lyngstad, I., Hagen, P.-M. \& Aune, O. (2016). Understanding pupils' hiding techniques in physical education. Sport, Education and Society, 21(8), 1127-1143.

Mjaavatn, P.-E. \& Skisland, J.-O. (2003). Fysisk aktivitet i skolehverdagen. Oslo: Helsedirektoratet.

Moen, K. M. (2011). "Shaking or stirring"? : a case-study of physical education teacher education in Norway. Doktoravhandling, Norges idrettshøgskole, Oslo.

Nordtug, B. \& Engelsrud, G. (2016). Boken som mangler, ord som går på tomgang og sykt flinke jenter: Kunnskap og helse. Tidsskrift for kjønnsforskning, (03-04), 3-20.

Ntoumanis, N., Barkoukis, V. \& Thøgersen-Ntoumani, C. (2009). Developmental Trajectories of Motivation in Physical Education: Course, Demographic Differences, and Antecedents. Journal of Educational Psychology, 101(3), 717-728.

Ntoumanis, N. \& Standage, M. (2009). Motivation in physical education classes: A selfdetermination theory perspective. Theory and Research in Education, 7(2), 194-202.

Ommundsen, Y. (2005). Kroppsøving: aktivitet eller læring? Kroppsøving, 6, 8-12.

Ommundsen, Y. (2012). Fysisk-motorisk ferdighet gjennom kroppsøving - et viktig bidrag til elevenes allmenndanning og læring i skolen. Norsk Pedagogisk Tidsskrift, 97(2), 155166.

Ommundsen, Y. \& Kvalo, S. E. (2007). Autonomy-Mastery, Supportive or Performance Focused? Different Teacher Behaviours and Pupils' Outcomes in Physical Education. Scandinavian Journal of Educational Research, 51(4), 385-413.

Redelius, K., Quennerstedt, M. \& Öhman, M. (2015). Communicating aims and learning goals in physical education: part of a subject for learning? Sport, Education and Society, 20(5), 641-655.

Ryan, R. M. \& Deci, E. L. (2017). Self-determination theory: Basic psychological needs in motivation, development, and wellness. New York: The Guilford Press.

Seippel, Ø., Sletten, M. A. \& Strandbu, Å. (2011). Ungdom og trening : endring over tid og sosiale skillelinjer. NOVA-rapport 3/2011. Hentet fra: http://www.nova.no/asset/4536/1/4536_1.pdf

Standage, M., Duda, J. L. \& Ntoumanis, N. (2005). A test of self-determination theory in school physical education. British Journal of Educational Psychology, 75, 411-433.

Säfvenbom, R. (2010). Om å lede de unge ut i fristelse - og det gode liv. I K. Steinsholt \& K. Pedersen Gurholt (red.), Aktive liv (s. 155-137). Trondheim: Tapir akademisk forlag, 2010.

Säfvenbom, R., Haugen, T. \& Bulie, M. (2015). Attitudes toward and Motivation for PE. Who Collects the Benefits of the Subject? Physical Education and Sport Pedagogy, 20(6), 629-646.

Ulstad, S. O., Halvari, H., Sørebø, Ø. \& Deci, E. L. (2018). Motivational predictors of learning strategies, participation, exertion, and performance in physical education: A randomized controlled trial. Motivation and Emotion, 42(4), 497-512. 
Utdanningsdirektoratet (2012). Endringer i faget kroppsøving Udir-8-2012. Hentet fra : https://www.udir.no/regelverkstolkninger/opplaring/Innhold-i-opplaringen/Udir-82012/

Utdanningsdirektoratet (2015). Læreplan i kroppsøving (KRO1-04). Hentet fra https://www.udir.no/kl06/KRO1-04

Van den Berghe, L., Vansteenkiste, M., Cardon, G., Kirk, D. \& Haerens, L. (2014). Research on self-determination in physical education: key findings and proposals for future research. Physical Education and Sport Pedagogy, 19(1), 97-121.

Walseth, K., Aartun, I. \& Engelsrud, G. (2017). Girls' bodily activities in physical education. How current fitness and sport discourses influence girls’ identity construction. Sport, Education and Society, 22(4), 442-459.

\section{Intervjuguider}

\section{Elever}

Innledning

Takk for at du er villig til å delta på dette intervjuet. Først vil vi forsikre deg om at alt du sier her, er konfidensielt. Ingen opptak fra dette intervjuet vil bli knyttet til ditt navn eller andre personidentifiserbare data. Er det greit at jeg tar opp intervjuet på bånd?

(Kort gjennomgang av passivt samtykke)

\section{Oppvarming}

1. Hva liker du å gjøre på fritiden?

2. Hvilke erfaringer har du fra idrett eller fysisk aktivitet?

\section{Hoveddel}

Det første vi skal snakke om er hvordan du opplever gym nå etter at du har begynt på videregående

3. Hvorfor tror du dere har gym på skolen?

a. Hva lærer du i gymmen?

b. Hva synes du bør være det viktigste i gymmen?

4. Hvordan opplever du å ha gym? (prøve å få fram ulike følelser som oppstår i forbindelse med kroppsøvingsfaget)

a. Trives du? Liker du faget?

b. Føler du deg trygg? glad?

c. Føler du at du kan være med å påvirke innholdet? Hva og hvordan, og hvordan påvirker det deg?

d. Føler du at aktivitetene/oppgavene er tilpasset deg?

e. Vil du bli sett og føler du deg sett av lærer?

5. Hva gjør at du deltar i kroppsøving?

a. Har læreren noe å si? Hva vektlegges?

b. Har aktivitetene noe å si?

c. Hvilken betydning har klassemiljøet? 
d. Vurdering (hva opplever du må til for å oppnå en god karakter? Utdyp)

6. Deltar du mer eller mindre nå enn på ungdomsskolen?

a. Hvis ikke, hvorfor?

b. A føle seg sett

c. Andre forhold

\section{Avslutning}

7. Gir gymtimene deg lyst til å være fysisk aktiv på fritiden? Hvorfor?

a. Er det noe med undervisningen, læreren eller annet?

8. Om du hadde hatt muligheten, er det noe du ville forandret i gymundervisningen?

a. Hvorfor?

9. Snakker du med foreldre/venner om gymtimene?

a. Er de interesserte i hva du lærer?

b. Synes de faget er viktig?

c. Hvilken ferdning tror du de har av faget?

10.Er det noe mer du har lyst til å fortelle?

\section{Kroppsøvingslærere}

Innledning

Takk for at dere er villig til å delta på dette intervjuet. Først vil vi forsikre om at alt dere sier her, er konfidensielt. Ingen opptak fra dette intervjuet vil bli knyttet til deres navn eller andre personidentifiserbare data. Er det greit at jeg tar opp intervjuet på bånd?

(Kort gjennomgang av passivt samtykke)

\section{Oppvarming}

1. Hvor lenge har dere jobbet som kroppsøvingslærere?

2. Hvilken formell bakgrunn?

\section{Hoveddel}

Didaktikk. Målet med de første spørsmålene er å fange hvordan didaktikk dere har brukt i prosjektklassene, og om dere har gjort noen forskjell i forhold til kontrollklassene. Da tenker jeg på...

3. Innhold, hva? Metode, hvordan? Vurderingsformer?

a. Hvorfor er dette viktig for elevene?

4. Hvordan presenterer dere faget for elevene?

a. I hvilket perspektiv setter dere faget? Hva er nytt i deres undervisning, eller hva har dere satt fokus på i prosjektklassene?

b. Hvorfor, utdyp, gi eksempler

c. Prestasjonsorientert eller oppgave/prosessorientert?

d. I hvilken grad bygger dere kroppsøvingsundervisningen på idrettstanker? 
e. Hva har vært nytt nå i forhold til skolens måte å undervise på? Systemnivå

f. Gjør dere forskjell i intervensjonsklassen og kontrollklassen?

g. Hvilke undervisningsmetoder benytter dere mest?

h. Hvilke fordeler/ulemper ser dere ved den mest brukte metoden?

i. I hvilken grad vektlegger dere elevmedvirkning - hvordan og hvorfor?

5. Føler dere at dere har lykkes?

a. På hvilken måte?

b. Hva kan årsaken til det være? Hvorfor?

c. De tre viktigste suksesskriteriene

6. Hva har vært de største utfordringene?

a. Hvordan har du/dere jobbet med utfordringene?

b. Økonomi, ressurser, tid, kommunikasjon, timeplan

Prosessen. Neste tema nå er prosessen dere har vœert gjennom. Altså hvordan har dere opplevd den?

7. Hvordan har du opplevd prosessen gjennom prosjektet?

a. Har det vært givende, stressende, gitt deg noe nytt som lærer?

b. Tidsforbruk og arbeidssituasjon

c. Hvilke valgmuligheter føler dere at dere har hatt i prosjektet?

d. Føler dere at deres kompetanse er blitt benyttet?

e. Samarbeid i egen seksjon

f. Samarbeid med andre lærere, ledelsen og prosjektgruppa

8. Har innstillingen til fysisk aktivitet og kroppsøving endret seg på skolen? (systemnivå)

a. I hvilken grad tenker du tiltaket er levedyktig?

i. Hvorfor?

Elevenes utvikling. Siste tema er hvordan dere har oppfattet elevenes utvikling etter prosjektet startet. Altså har dere sett noen utvikling/forandring ... hva går disse forandringene ut på ...

9. Læringsmiljø, klassemiljø, deltakelse, aktivitetsnivå, motivasjon

10.Foreldrenes tilbakemeldinger

\section{Avslutning}

11.Vi har funnet at motivasjonen for kroppsøving endres i positiv retning etter 1. år med ordinær kroppsøving på videregående skole - hvorfor? (trivsel, iver, deltakelse, mestring)

12.Har din motivasjon for livsstil og helse forandret seg? 